Bull. Chem. Soc. Ethiop. 2019, 33(1), 77-90.

ISSN 1011-3924

(C) 2019 Chemical Society of Ethiopia and The Authors

Printed in Ethiopia

DOI: https://dx.doi.org/10.4314/bcse.v33i1.8

\title{
TIN(IV) SCHIFF BASE COMPLEXES: SYNTHESIS, THERMODYNAMIC AND ANTI BACTERIAL INVESTIGATION, EXPERIMENTAL AND THEORETICAL STUDIES
}

\author{
Sheida Esmaielzadeh ${ }^{{ }^{*}}$ and Mohammad Sharif-Mohammadi ${ }^{2}$ \\ ${ }^{1}$ Department of Chemistry, Darab branch, Islamic Azad University, Darab, Iran \\ ${ }^{2}$ Department of Chemistry, Firozabad branch, Islamic Azad University, Firoozabad, Iran
}

(Received December 29, 2017; Revised November 10, 2018; Accepted November 14, 2018)

\begin{abstract}
A series of five coordinated diorganotin(IV) unsymmetrical Schiff base complexes have been synthesized. The structure determination and characterization of these complexes were made on the basis of UVVis, IR, $\left({ }^{1} \mathrm{H}\right.$ and $\left.{ }^{119} \mathrm{Sn}\right)$ NMR spectroscopy as well as elemental analysis. The binding site of the ligand was identified by IR spectroscopic measurement. Computational analyses at the level of DFT were performed to study its electronic and molecular structures. The molecular geometry, infrared vibrational frequencies, HOMO-LUMO energy gap, dipole moment, Mulliken charges, HF energies were calculated. The theoretical results were consistent with the experimental data reported. The Schiff base ligands and synthesized tin(IV) complexes were screened for their in vitro growth inhibiting activity against different strains of bacteria. Results indicated that the complexes exhibited good antibacterial activities than the ligands. Also the thermodynamic formation constants of the Schiff bases as donors with $\mathrm{Me}_{2} \mathrm{SnCl}_{2}$ as an acceptor were measured using UV-Vis spectrophotometric titration for 1:1 complex formation at constant ionic strength $\left(\mathrm{I}=0.1 \mathrm{M} \mathrm{NaClO}_{4}\right)$ and at $25^{\circ} \mathrm{C}$.
\end{abstract}

KEY WORDS: Tin(IV) complexes, Thermodynamic parameter, Biological activity, Computational analyses

\section{INTRODUCTION}

The discovery of several new organotin species and new applications has led to a renewed interest in organotin complexes. A large number of organotin compound are used in several areas such as pharmaceuticals, pesticides, stabilizers, fire retardants, miticides, molluscicides, marine antifouling paints, surface disinfectants and wood preservatives and many more [1-4]. On the other hand, Schiff base ligands received instant and enduring popularity because they have played a seminal role in the development of modern coordination chemistry, as well as they can also be found at key points in the development of inorganic chemistry, catalysis, pigment and dyes, medicinal imaging, optical materials and thin films [5-8]. Schiff base ligands containing hetero atoms such as $\mathrm{N}, \mathrm{O}$, and $\mathrm{S}$ show a broad biological activity and are of special interest because of their variety of ways in which they are interacted to metal ions. Schiff base in neutral and deprotonated forms react with organotin(IV) halides and the complexes extensively studied because they have some characteristics properties like manifestations of novel structures, thermal stability, high synthesis flexibility, medicinal utility, industrial applications and relevant biological properties [9-12]. In addition to their special antimicrobial activities, organotin(IV) compound with Schiff bases present an interesting variety of structural possibilities, so that a remarkable diversity in structure may be observed even when only a small change in the chemistry occurs [13].

The present study will entail a description of synthesis and characterization of some tin(IV) complexes with Schiff bases containing sulfur, nitrogen and oxygen atoms, and illustration of the geometrical structure by using spectral analysis. By comparing the spectral and thermodynamic properties of Schiff base ligands and their complexes, we aimed to investigate the effects of different electronic and steric behaviors. Moreover, the density functional theory computational calculations were done for tin(IV) Schiff base complexes for comparing with experimental results. Also, the present work involves antibacterial activities against grampositive and gram-negative bacterial for the Schiff base ligand and their complexes.

*Corresponding author. E-mail: esmaielzadehsheida@yahoo.com

This work is licensed under the Creative Commons Attribution 4.0 International License 


\section{EXPERIMENTAL}

\section{Materials and physical measurements}

All chemicals and reagents were commercially available and were grade quality. All the reagents were used as received. The infrared spectra of the solid compounds were recorded on a Shimadzu FTIR 8300 spectrophotometer in the range $4000-200 \mathrm{~cm}^{-1}$ as $\mathrm{KBr}$ discs. The melting points were determined in open capillaries with electronic melting point apparatus. $\mathrm{C}, \mathrm{H}, \mathrm{N}, \mathrm{S}$ analyses were carried on a Termo Fininngan-Flash-1200. The ${ }^{1} \mathrm{H}$ and ${ }^{119} \mathrm{Sn}$ NMR spectral data were obtained on Bruker Avance DPZ $500 \mathrm{MHz}$ spectrometer using TMS and $\mathrm{SnMe}_{4}$ as references and chemical shift are expressed in ppm. The conductivity were performed using Jenway 4310 conductivity meter and a diptype cell with a platinized electrode in DMF having $10^{-3} \mathrm{M}$ solutions of the metal complexes at room temperature. UV-Vis spectra were recorded in DFT with T80 UV-Vis spectrophotometers.

\section{Preparation of ligands and corresponding complexes}

The unsymmetrical Schiff base ligands was synthesized by stirring at room temperature a 1:1 molar ratio mixture of methyl-2-(1-methyl-2'-amino-ethane)amino-1-cyclopentenedithiocarboxylate [HcdMeen] and the substituted salicylaldehyde in methanolic solution following a reported method [14-16]. The resultant yellow powder was recrystallized from methanol/ chloroform 2:1 (v:v). To a stirred solution of methyl-2-\{[1-methyl-2-(2-hydroxy-5-methoxyphenyl)methylidynenitrilo]ethyl $\}$ amino-1-cyclopentenedithiocarboxylate [ $\left.\mathrm{H}_{2} \mathrm{~cd} 5 \mathrm{OMesalMen}\right]$, methyl-2-\{[1-methyl-2-(2-hydroxyphenyl)methyllidynenitrilo]ethyl $\}$-amino-1-cyclopentenedithiocarboxylate, [ $\mathrm{H}_{2}$ cdsalMeen], methyl-2-\{[1-methyl-2-(2-hydroxy-5-bromophenyl)methylidynenitrilo]ethyl $\}$ amino-1-cyclopentenedithiocarboxylate, $\left[\mathrm{H}_{2} \mathrm{~cd} 5\right.$-BrsalMeen $]$, methyl-2-\{[1methyl-2-(2-hydroxy-5-chlorophenyl)methylidynenitrilo] ethyl\}-amino-1-cyclopentene-dithiocarboxylate, and [ $\left.\mathrm{H}_{2} \mathrm{~cd} 5-\mathrm{ClsalMeen}\right]$ methyl-2-\{[1-methyl-2-(2-hydroxy-5-nitrophenyl)methylidynenitrilo] ethyl amino-1-cyclopentenedithiocarboxylate, $\left[\mathrm{H}_{2} \mathrm{~cd} 5-\mathrm{NO}_{2}\right.$ salMeen $](1 \mathrm{mmol})$ in $15 \mathrm{~mL}$ of chloroform/methanol 2:1(v:v), a solution of $\mathrm{Me}_{2} \mathrm{SnCl}_{2}(1 \mathrm{mmol})$ in $15 \mathrm{~mL}$ of methanol was added slowly at r.t. The mixture was then stirred for 4-6 h. During this period, the yellow solid precipitate formed was filtered and washed with petroleum ether (Figure 1).

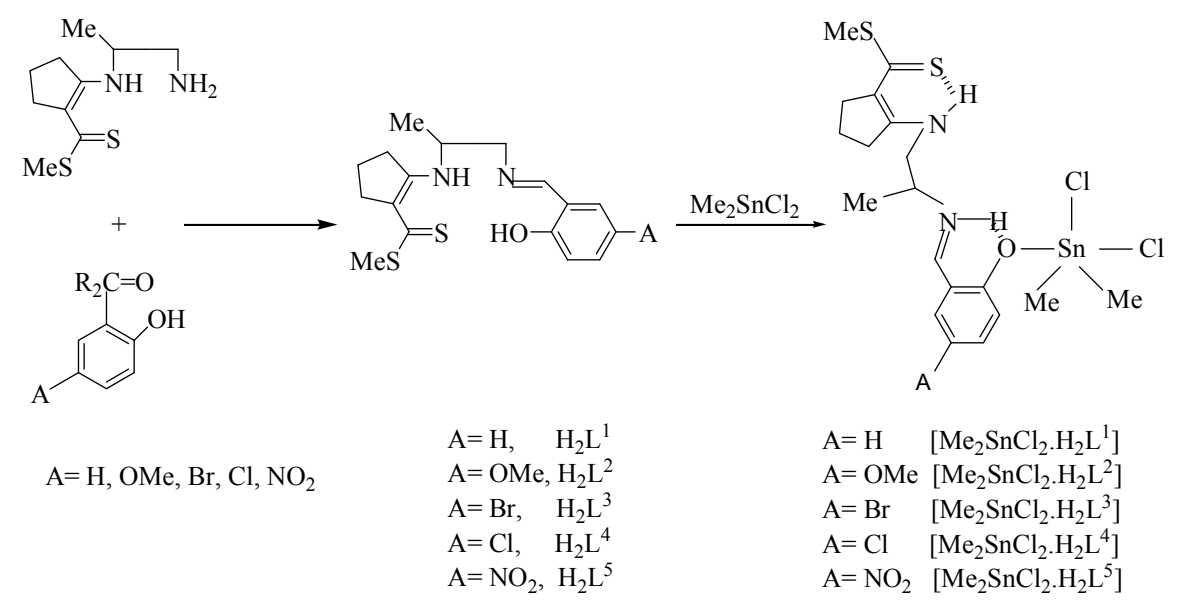

Figure 1. Schematic representation of the Sn(IV) complexes. 


\section{Thermodynamic studies of complex formation}

The formation constants, $K_{f}$, of the $\mathrm{Sn}(\mathrm{IV})$ complexes were determined by spectrophotometric titration of the ligands $\mathrm{H}_{2} \mathrm{cdX}$ salMeen with various concentration of the solution of dimethyltin(IV)dichloride at constant ionic strength $\left(0.1 \mathrm{M} \mathrm{NaClO}_{4}\right)$ at $25{ }^{\circ} \mathrm{C}$. The interaction of $\mathrm{NaClO}_{4}$ with the ligands was negligible. In a typical measurement, $2.5 \mathrm{~mL}$ of the ligand solution $\left(10^{-5} \mathrm{M}\right)$ in DMF was transferred into the thermostated cell compartment of UV-Visible instrument, and was titrated by the dimethyltin(IV)dichloride solution $\left(10^{-5}-10^{-4} \mathrm{M}\right)$ in DMF. The titration was performed by adding aliquots of the tin ion with a Hamilton $\mu \mathrm{L}$ syringe to the ligand. The UV-Vis spectra were recorded in the range 290-600 $\mathrm{nm}$ about $5 \mathrm{~min}$ after each addition. The formed product showed different absorption from the free ligand, while the metal ion solution shows no absorption at those wavelengths. As an example, the variation of the electronic spectra for $\left[\mathrm{H}_{2} \mathrm{~L}^{5}\right]$ titrated with various concentration of dimethyltin(IV)dichloride at $25{ }^{\circ} \mathrm{C}$ in DMF. The same procedure was followed for other systems. The electronic spectra of the formed complexes at the end of titration were the same as the electronic spectra of the separately synthesized complexes.

\section{Determination of bacteriological activity}

Bioactivities were investigated using agar-well diffusion method [17]. The synthesized Schiff base ligands and their tin(IV) complexes were screened for their biological activities by using two bacteria namely Staphylococcus aureus and Escherichia coli by the reported method. The bacteria were subcultured in agar medium. Recommended concentration $(100 \mu \mathrm{L})$ of the test sample $1 \mathrm{mg} / \mathrm{mL}$ in DMSO was introduced in the respective wells. The Petri dishes were incubated immediately for 24 hours at $37{ }^{\circ} \mathrm{C}$. Activity was determined by measuring the diameter of the zone showing complete inhibition $(\mathrm{mm})$. Growth inhibition was compared with standard drugs. In order to clarify the role of DMSO on the biological screening, separate studies were carried out with solvent DMSO only and it showed no activity against any microbial strains.

\section{Theoretical methods}

The quantum chemical calculations were performed using Gaussian 03 package [18]. The local minimum energy, Mulliken charges, dipole moment, HOMO-LUMO energy and its band gap of the optimized structures for Sn(IV) complexes was computed at Becke three parameter hybrid function (B3LYP) using LANL2DZ and 6-311G** basis sets for all atoms including tin [19]. By the use of LANL2DZ basis set, computational time and convergence difficulties were considerably reduced. LANL2DZ basis set uses pseudopotential, the results are very close to the experimental data. This does not necessarily substantiate preference of LANL2DZ basis set over 6-311G**. Many descriptors were used to recognize and correlate some physical and chemical properties. The calculated vibrational spectra of the optimized complexes were assigned based on vibrational mode analysis with the aid of the DFT method.

\section{RESULTS AND DISCUSSION}

\section{Elemental analysis}

The stoichiometry of the tin(IV) complexes were confirmed by their elemental analysis. Experimental and calculated elemental compositions of the complexes are given in Table 1. The analytical data are in good agreement with the proposed structures of the complexes (Figure 1). The metal/ligand ratio was found to be $1: 1$ has been arrived at by estimating the carbon, hydrogen, nitrogen and sulfur contents of the complexes. Solutions of these complexes no react with silver nitrate indicating the existence of chloride in inside coordination sphere of the tin ion. 


\section{Molar conductance}

The tin(IV) complexes under investigation are quite stable at ambient temperature. They are sparingly soluble in donor solvents such as DMF and DMSO. The molar conductance of these complexes (Table 1) indicating that it is essentially a non-electrolyte in this solvent [20]. The very low conductance for these complexes is strong evidence that the Schiff base is coordinated to the tin atom as an unnegatively charged ligand and that the two chloro ligands are also coordinated to the tin ion.

\section{Infrared spectra}

The IR spectra give enough information to elucidate the nature of bonding of the ligand to the metal ions. The IR spectra of free Schiff base were compared with the spectra of the tin(IV) complexes in order to study the binding mode of the Schiff base to Sn(IV) ion in the new complexes. In Table 2 the main infrared bands and their assignments are shown. In this spectra of free ligand and new complexes no band is observed in the region $3500-3600 \mathrm{~cm}^{-1}$ attributable to the stretching vibration of the free phenolic $\mathrm{OH}$ group indicating that the ring formed by the intramolecular hydrogen bond in the ligand which, is retained in complexes. Weak broad absorption bands appearing in the range of 2800-2900 $\mathrm{cm}^{-1}$ for the free Schiff base ligands are assigned to $v(\mathrm{O}-\mathrm{H})$ and $v(\mathrm{~N}-\mathrm{H})$ overlapping with the $v(\mathrm{C}-\mathrm{H})$ [16]. These bands are observed to shift slightly to higher frequency due to the coordination of phenolic oxygen atom with tin and changes in hydrogen bonding [21]. The strong bands at $1622-1649 \mathrm{~cm}^{-1}$, which can be attributed to $v(\mathrm{C}=\mathrm{N})$ stretching frequency on Schiff base ligands [16]. This band showed a major shift to higher frequency $\left(1638-1659 \mathrm{~cm}^{-1}\right)$ is suggesting the complex formation and the proton transfer from phenolic oxygen atom to the imine nitrogen atom [22]. In the spectra of tin(IV) complexes a sharp peak at $1558-1567 \mathrm{~cm}^{-1}$ due to the $\mathrm{v}(\mathrm{C}=\mathrm{O})$ providing evidence of participation of the phenolic oxygen in the tin-ligand bonding [23]. The aromatic $v(\mathrm{C}=\mathrm{C})$ stretching frequency occurs at 1479-1497 $\mathrm{cm}^{-1}$ [24]. The characteristic sulfur vibration of $v(\mathrm{C}-\mathrm{S})$ appearing at 763$798 \mathrm{~cm}^{-1}[16]$.

Table 1. Physical properties and analytical data of the synthesized tin(IV) complexes.

\begin{tabular}{|c|c|c|c|c|c|c|c|c|c|}
\hline Complexes & Empirical formula & $\begin{array}{c}\text { Formula } \\
\text { weight }\end{array}$ & $\begin{array}{c}\text { Yield } \\
(\%)\end{array}$ & $\begin{array}{c}\Lambda_{\mathrm{M}}\left(\Omega^{-1}\right. \\
\left.\text { cm }^{2} \mathrm{~mol}^{-1}\right)\end{array}$ & $\begin{array}{c}\text { m.p.p. } \\
\left({ }^{\circ} \mathrm{C}\right)\end{array}$ & \multicolumn{4}{|c|}{$\begin{array}{c}\text { Anal. found } \\
\text { (calc.) (\%) }\end{array}$} \\
\hline & & & & & & $\mathrm{C}$ & $\mathrm{H}$ & $\mathrm{N}$ & $\mathrm{S}$ \\
\hline$\left[\mathrm{Me}_{2} \mathrm{SnCl}_{2} \cdot \mathrm{H}_{2} \mathrm{~L}^{1}\right]$ & $\mathrm{C}_{19} \mathrm{H}_{28} \mathrm{~N}_{2} \mathrm{Cl}_{2} \mathrm{OS}_{2} \mathrm{Sn}$ & 554.15 & 49 & 20 & 170 & $41.07(41.18)$ & $5.21(5.09)$ & $5.11(5.06)$ & $11.64(11.57)$ \\
\hline$\left[\mathrm{Me}_{2} \mathrm{SnCl}_{2} \cdot \mathrm{H}_{2} \mathrm{~L}^{2}\right]$ & $\mathrm{C}_{20} \mathrm{H}_{30} \mathrm{~N}_{2} \mathrm{Cl}_{2} \mathrm{O}_{2} \mathrm{~S}_{2} \mathrm{Sn}$ & 584.18 & 53 & 20 & 173 & $41.22(41.12)$ & $5.46(5.18)$ & $4.66(4.80)$ & $10.75(10.98)$ \\
\hline$\left[\mathrm{Me}_{2} \mathrm{SnCl}_{2} \cdot \mathrm{H}_{2} \mathrm{~L}^{3}\right]$ & $\mathrm{C}_{19} \mathrm{H}_{27} \mathrm{~N}_{2} \mathrm{Cl}_{2} \mathrm{OS}_{2} \mathrm{BrSn}$ & 633.05 & 49 & 15 & 161 & $35.93(36.05)$ & $4.21(4.30)$ & $4.697(4.43)$ & $10.36(10.13)$ \\
\hline$\left[\mathrm{Me}_{2} \mathrm{SnCl}_{2} \cdot \mathrm{H}_{2} \mathrm{~L}^{4}\right]$ & $\mathrm{C}_{19} \mathrm{H}_{27} \mathrm{~N}_{2} \mathrm{Cl}_{3} \mathrm{OS} \mathrm{S} \mathrm{Sn}$ & 588.60 & 51 & 17 & 168 & $39.13(38.77)$ & $4.54(4.62)$ & $5.05(4.76)$ & $11.03(10.89)$ \\
\hline$\left[\mathrm{Me}_{2} \mathrm{SnCl}_{2} \cdot \mathrm{H}_{2} \mathrm{~L}^{5}\right]$ & $\mathrm{C}_{19} \mathrm{H}_{27} \mathrm{~N}_{3} \mathrm{Cl}_{2} \mathrm{O}_{3} \mathrm{~S}_{2} \mathrm{Sn}$ & 599.15 & 47 & 21 & 157 & $38.39(38.09)$ & $4.68(4.54)$ & $7.15(7.01)$ & $10.51(10.70)$ \\
\hline
\end{tabular}

Table 2. Selected experimental and theoretical IR frequencies $\left(\mathrm{cm}^{-1}\right)$ of Sn(IV) Schiff base complexes.

\begin{tabular}{|c|c|c|c|c|c|c|c|}
\hline & Complexes & $\begin{array}{c}v(\mathrm{Sn}-\mathrm{O}) \\
\mathrm{m}\end{array}$ & $\begin{array}{c}v(\mathrm{C}-\mathrm{S}) \\
\mathrm{br}, \mathrm{m}\end{array}$ & $\begin{array}{c}v(\mathrm{C}=\mathrm{C}) \\
\mathrm{s}\end{array}$ & $\begin{array}{c}v(\mathrm{C}=\mathrm{O}) \\
\mathrm{s}\end{array}$ & $\begin{array}{c}v(\mathrm{C}=\mathrm{N}) \\
\mathrm{vs}\end{array}$ & $\begin{array}{c}v(\mathrm{C}-\mathrm{H}) \\
\mathrm{m}\end{array}$ \\
\hline \multirow{4}{*}{$\begin{array}{c}\text { Experimental } \\
\text { frequencies }\end{array}$} & {$\left[\mathrm{Me}_{2} \mathrm{SnCl}_{2} \cdot \mathrm{H}_{2} \mathrm{~L}^{1}\right]$} & 591 & 763 & 1480 & 1563 & 1638 & 2867 \\
\cline { 2 - 8 } & {$\left[\mathrm{Me}_{2} \mathrm{SnCl}_{2} \cdot \mathrm{H}_{2} \mathrm{~L}^{2}\right]$} & 584 & 790 & 1485 & 1558 & 1659 & 2925 \\
\cline { 2 - 8 } & {$\left[\mathrm{Me}_{2} \mathrm{SnCl}_{2} \cdot \mathrm{H}_{2} \mathrm{~L}^{3}\right]$} & 587 & 766 & 1475 & 1567 & 1638 & 2917 \\
\cline { 2 - 8 } & {$\left[\mathrm{Me}_{2} \mathrm{SnCl}_{2} \cdot \mathrm{H}_{2} \mathrm{~L}^{4}\right]$} & 587 & 798 & 1477 & 1565 & 1641 & 2971 \\
\cline { 2 - 8 } & {$\left[\mathrm{Me}_{2} \mathrm{SnCl}_{2} \cdot \mathrm{H}_{2} \mathrm{~L}^{5}\right]$} & 590 & 774 & 1473 & 1559 & 1657 & 2944 \\
\hline \multirow{4}{*}{$\begin{array}{c}\text { Calculated } \\
\text { frequencies }\end{array}$} & {$\left[\mathrm{Me}_{2} \mathrm{SnCl}_{2} \cdot \mathrm{H}_{2} \mathrm{~L}^{1}\right]$} & 590 & 767 & 1495,1475 & 1567 & 1642 & 2872 \\
\cline { 2 - 9 } & {$\left[\mathrm{Me}_{2} \mathrm{SnCl}_{2} \cdot \mathrm{H}_{2} \mathrm{~L}^{2}\right]$} & 589 & 785 & $1750,1560,1477$ & 1561 & 1663 & 2927 \\
\cline { 2 - 8 } & {$\left[\mathrm{Me}_{2} \mathrm{SnCl}_{2} \cdot \mathrm{H}_{2} \mathrm{~L}^{3}\right]$} & 585 & 769 & $1492,1483,1476$ & 1573 & 1645 & 1921 \\
\cline { 2 - 8 } & {$\left[\mathrm{Me}_{2} \mathrm{SnCl}_{2} \cdot \mathrm{H}_{2} \mathrm{~L}^{4}\right]$} & 586 & 802 & $1492,1481,1476$ & 1562 & 1645 & 2973 \\
\cline { 2 - 8 } & {$\left[\mathrm{Me}_{2} \mathrm{SnCl}_{2} \cdot \mathrm{H}_{2} \mathrm{~L}^{5}\right]$} & 593 & 779 & $1490,1470,1474$ & 1565 & 1661 & 2949 \\
\hline
\end{tabular}

vs: very strong; s: strong; m: medium; w: weak; br: broad. 
New bands in the range of 580-590 $\mathrm{cm}^{-1}$ which are not present in the free Schiff base are due to $v(\mathrm{Sn}-\mathrm{O})$ vibration [25] and the appearance of the vibrations support the involvement of the oxygen atoms of phenolic group complexation with the tin ion under investigations. Two sharp peaks at around 1300 and $1550 \mathrm{~cm}^{-1}$ are typical of nitro group in $\left[\mathrm{Me}_{2} \mathrm{SnCl}_{2} \cdot \mathrm{H}_{2} \mathrm{~cd} 5 \mathrm{NO}_{2}\right.$ salMeen] [16].

${ }^{1} H$ and ${ }^{119}$ Sn NMR spectra

The NMR spectrum is recorded to confirm the binding sites during the complexation. The NMR data are given in Table 3. The chemical shift observed for the $-\mathrm{OH}$ and $-\mathrm{NH}$ protons in free Schiff base ligands $(\delta 12.45-14.06 \mathrm{ppm})$ and $(\delta 12.30-12.38 \mathrm{ppm})$ was observed in all complexes. The deshielding of this group and shifted down field in complexes may be due to bonding of the oxygen to the tin(IV) ion which lead to decrease of the density of electrons on the hydroxyl group. The same results were confirmed by the IR spectroscopy. The signal at 8-9 ppm were assigned to imine proton $(\mathrm{HC}=\mathrm{N})$ is not flanked by satellites, this is an indicating that the $\mathrm{N}$ atom is not coordinated to tin(IV) [26]. The lack of down field shift in the position of the signal attributable to $\mathrm{S}_{-} \mathrm{CH}_{3}(\delta 2.55-2.57 \mathrm{ppm}$ in free ligand) indicates no participitation of the $-\mathrm{C}=\mathrm{S}$ group in binding [27]. The ligand shows multiplet signal in the region $\delta 6.83-8.23 \mathrm{ppm}$ for the aromatic protons and these values are remains almost same position in the spectra of $\mathrm{Sn}(\mathrm{IV})$ complexes. ${ }^{1} \mathrm{H}$ NMR spectra of Schiff base ligands and their complexes show one peak at chemical shift ca. 1.39-1.41, this singlet peak with three proton integration has been assigned to the methyl group on diamine bridge. The high field regions in the spectra of dimethyl tin show signal at $1.15 \mathrm{ppm}$ for all complexes and these are due to the methyl groups in the organotin fragment. These signals have satellites due to coupling with tin $\left({ }^{2} \mathrm{~J}{ }^{119} \mathrm{Sn}-\mathrm{H} 71.0\right.$ and $77.1 \mathrm{~Hz}$ ). The data describe above are all consistent with those observed for the other five coordinated diorganotin complexes containing Schiff base ligands [28].

The value of chemical shift ${ }^{119} \mathrm{Sn}$ spectra expresses the coordination number of the nucleus in the related metal complexes. In general, ${ }^{119} \mathrm{Sn}$ chemical shifts move to lower frequency with increasing coordination number of the nuclei. In order to confirm the geometry of the complexes, ${ }^{119}$ Sn NMR spectra were recorded. The spectra in each complex show only a sharp singlet, indicating the formation of a single species. The ${ }^{119} \mathrm{Sn}$ NMR spectra of all titled complexes $\left[\mathrm{Me}_{2} \mathrm{SnCl}_{2} \cdot \mathrm{H}_{2} \mathrm{~L}^{1-5}\right]$ give sharp signals at $-166.65,-163.55,-161.43,-161.76,-168.93$ ppm, respectively, which is indicative of five coordinated environment around the tin atom. Thus on the basis of the above evidences it is suggested that the geometry of the resulting tin complexes be characterized as trigonal bipyramidal [21, 29, 30]. The proposed structures of newly synthesized complexes are shown in Figure 1.

Table 3. ${ }^{1} \mathrm{H}$ and ${ }^{119} \mathrm{NMR}$ spectral data of prepared complexes $(\delta / \mathrm{ppm})$.

\begin{tabular}{|c|c|c|c|c|c|c|}
\hline & $\mathrm{H}_{2} \mathrm{~L}^{\mathrm{T}}$ & {$\left[\mathrm{Me}_{2} \mathrm{SnCl}_{2} \cdot \mathrm{H}_{2} \mathrm{~L}^{1}\right]$} & $\mathrm{H}_{2} \mathrm{~L}^{2}$ & {$\left[\mathrm{Me}_{2} \mathrm{SnCl}_{2} \cdot \mathrm{H}_{2} \mathrm{~L}^{2}\right]$} & $\mathrm{H}_{2} \mathrm{~L}^{3}$ & {$\left[\mathrm{Me}_{2} \mathrm{SnCl}_{2} \cdot \mathrm{H}_{2} \mathrm{~L}^{3}\right]$} \\
\hline & $\begin{array}{l}1.41 \quad(\mathrm{~d}, \quad 3 \mathrm{H}, \\
\mathrm{Me}),^{2.56}(\mathrm{~s}, 3 \mathrm{H}, \\
\left.\mathrm{SCH}_{3}\right), \quad 23.54-\end{array}$ & $\begin{array}{l}1.15(\mathrm{~s}, 6 \mathrm{H}, \mathrm{Sn}- \\
\mathrm{Me}), 1.41(3 \mathrm{H}, \mathrm{d} \\
\mathrm{Me}), 2.56(3 \mathrm{H}, \mathrm{s}\end{array}$ & 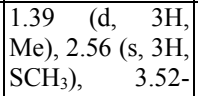 & $\begin{array}{l}1.15(\mathrm{~s}, 6 \mathrm{H}, \mathrm{Sn}- \\
\mathrm{Me}), 1.39(3 \mathrm{H}, \mathrm{d}, \\
\mathrm{Me}), 2.56(3 \mathrm{H}, \mathrm{s}\end{array}$ & $\mid \begin{array}{ccc}1.39 & (\mathrm{~d}, & 3 \mathrm{H} \\
\mathrm{Me}), & 2.57 & (\mathrm{~s}, \\
3 \mathrm{H}, & \left.\mathrm{SCH}_{3}\right)\end{array}$ & $\begin{array}{l}1.15(\mathrm{~s}, 6 \mathrm{H}, \mathrm{Sn}- \\
\mathrm{Me}), 1.39(3 \mathrm{H}, \mathrm{d} \\
\mathrm{Me}), 2.56(3 \mathrm{H}, \mathrm{s}\end{array}$ \\
\hline & 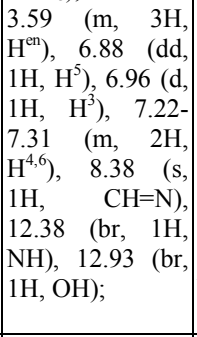 & 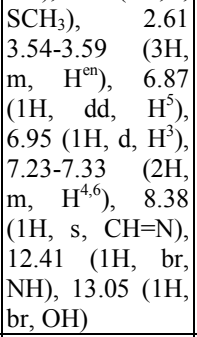 & 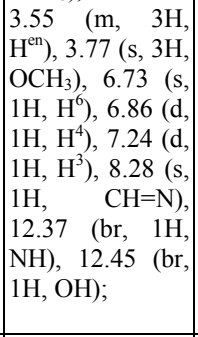 & 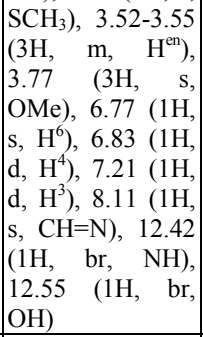 & $\begin{array}{lrr}3.49 & -3.88 & (\mathrm{~m}, \\
3 \mathrm{H}, & \left.\mathrm{H}^{\mathrm{en}}\right), & 6.83 \\
(\mathrm{~d}, & 1 \mathrm{H}, & \left.\mathrm{H}^{3}\right), \\
7.34 & (\mathrm{~s}, & 1 \mathrm{H}, \\
\left.\mathrm{H}^{6}\right) & 7.40 & (\mathrm{~d}, \\
1 \mathrm{H}, & \left.\mathrm{H}^{4}\right), & 8.27 \\
(\mathrm{~s}, & 1 \mathrm{H}, \\
\mathrm{CH}=\mathrm{N}), & 12.33 \\
(\mathrm{br}, & 1 \mathrm{H}, & \mathrm{NH}), \\
12.93 & (\mathrm{br}, & 1 \mathrm{H}, \\
\mathrm{OH}) & \end{array}$ & 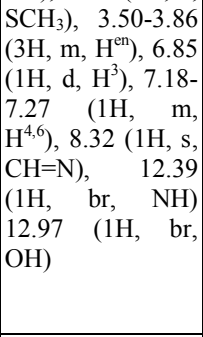 \\
\hline MR & & \begin{tabular}{|l|}
-166.65 \\
\end{tabular} & & -163.55 & & -161.43 \\
\hline
\end{tabular}

Bull. Chem. Soc. Ethiop. 2019, 33(1) 
Table 3. Continues

\begin{tabular}{|c|c|c|c|c|}
\hline & $\mathrm{H}_{2} \mathrm{~L}^{4}$ & {$\left[\mathrm{Me}_{2} \mathrm{SnCl}_{2} \cdot \mathrm{H}_{2} \mathrm{~L}^{4}\right]$} & $\mathrm{H}_{2} \mathrm{~L}^{5}$ & {$\left[\mathrm{Me}_{2} \mathrm{SnCl}_{2}{ }^{5} \cdot \mathrm{H}_{2} \mathrm{~L}\right]$} \\
\hline $\begin{array}{l}{ }^{1} \mathrm{H} \text { NMR } \\
\text { data }\end{array}$ & 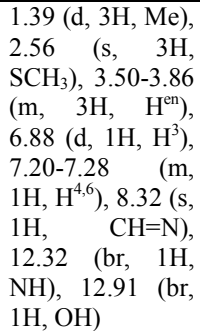 & $\begin{array}{l}1.15(\mathrm{~s}, 6 \mathrm{H}, \mathrm{Sn}-\mathrm{Me}), \\
1.39(3 \mathrm{H}, \mathrm{d}, \mathrm{Me}), \\
2.57\left(3 \mathrm{H}, \mathrm{s}, \mathrm{SCH}_{3}\right), \\
3.49-3.88 \quad(3 \mathrm{H}, \mathrm{m}, \\
\left.\mathrm{H}^{\mathrm{en}}\right), 6.80(1 \mathrm{H}, \mathrm{d}, \\
\left.\mathrm{H}^{3}\right), 7.32\left(1 \mathrm{H}, \mathrm{s}, \mathrm{H}^{6}\right), \\
7.38\left(1 \mathrm{H}, \mathrm{d}, \mathrm{H}^{4}\right), 8.27 \\
(1 \mathrm{H}, \mathrm{s}, \mathrm{CH}=\mathrm{N}), 12.38 \\
(1 \mathrm{H}, \mathrm{br}, \mathrm{NH}), 13.01 \\
(1 \mathrm{H}, \mathrm{br}, \mathrm{OH})\end{array}$ & $\begin{array}{l}1.43(\mathrm{~d}, 3 \mathrm{H}, \mathrm{Me}), 2.55 \\
\left(\mathrm{~s}, 3 \mathrm{H}, \mathrm{SCH}_{3}\right), 3.61- \\
3.66\left(\mathrm{~m}, 3 \mathrm{H}, \mathrm{H}^{\mathrm{en}}\right), 6.99 \\
\left(\mathrm{~d}, 1 \mathrm{H}, \mathrm{H}^{3}\right), 8.20-8.23 \\
\left(\mathrm{~m}, 2 \mathrm{H}, \mathrm{H}^{4,6}\right), 8.46(\mathrm{~s}, \\
1 \mathrm{H}, \mathrm{CH}=\mathrm{N}), 12.30(\mathrm{br}, \\
1 \mathrm{H}, \mathrm{NH}), 14.06(\mathrm{br}, \\
1 \mathrm{H}, \mathrm{OH})\end{array}$ & $\begin{array}{l}1.15(\mathrm{~s}, 6 \mathrm{H}, \mathrm{Sn}-\mathrm{Me}), \\
1.43(3 \mathrm{H}, \mathrm{d}, \mathrm{Me}), 2.55 \\
\left(3 \mathrm{H}, \mathrm{s}, \mathrm{SCH}_{3}\right), 3.61- \\
3.66\left(3 \mathrm{H}, \mathrm{m}, \mathrm{H}^{\mathrm{en}}\right), 6.97 \\
\left(1 \mathrm{H}, \mathrm{d}, \mathrm{H}^{3}\right), 8.18-8.20 \\
\left(2 \mathrm{H}, \mathrm{m}, \mathrm{H}^{4,6}\right), 8.46(1 \mathrm{H}, \\
\mathrm{s}, \mathrm{CH}=\mathrm{N}), 12.37(1 \mathrm{H}, \\
\text { br, NH), 14.14 (1H, br, } \\
\mathrm{OH}) ;\end{array}$ \\
\hline $\begin{array}{l}{ }^{119} \mathrm{Sn} \\
\mathrm{NMR} \text { data }\end{array}$ & & -161.76 & & -168.93 \\
\hline
\end{tabular}

Therefore, it is clear from these results that the data obtained from the elemental analysis, IR and NMR spectral measurements are in agreement with each other.

\section{$U V$-Vis absorption spectra}

The electronic absorption spectra of all the synthesized ligands and their complexes at very low concentrations $\left(\sim 10^{-4} \mathrm{M}\right.$ range) are recorded in DMF solution. The ligands exhibit the band at 312-314 and 395-398 $\mathrm{nm}$ can be assigned to intra ligand to $\pi \rightarrow \pi^{*}$ and $\mathrm{n} \rightarrow \pi^{*}$ transition [16]. Complex formation with dimethyltin(IV)dichloride results changes of the spectra took place in the UV-Vis region (250-600 nm) of $\pi \rightarrow \pi^{*}$ and $n \rightarrow \pi^{*}$ absorption band upon this interaction. After coordination of Schiff base to $\mathrm{Me}_{2} \mathrm{SnCl}_{2}$, the original peaks of the Schiff base ligands changed and have a red shift. A new peak is appeared in 460-470 $\mathrm{nm}$ regions. It seems that this is an LMCT from $\mathrm{n}_{\mathrm{O}}$ to $\mathrm{Sn}(\mathrm{IV})$ via coordination of Schiff base ligand to dimethyltindichloride [31].

\section{The formation constants and the thermodynamic free energy interpretations}

To interpret the steric and the electronic parameters of the ligands on the formation constants and the thermodynamic free energy of the complexation, the interaction between five ligands $\left(\mathrm{H}_{2} \mathrm{~L}^{1-5}\right)$ and dimethyltindichloride $\left(\mathrm{Me}_{2} \mathrm{SnCl}_{2}\right)$ was carried out by UV-Vis absorption spectroscopy through titration of the ligands with various concentrations of the $\mathrm{Sn}(\mathrm{IV})$ ion at 25 ${ }^{\circ} \mathrm{C}$. The complex formation constants, $K_{\mathrm{f}}$, were calculated using SQUAD computer program [32], designed to calculate the best values for the formation constants of the proposed equation model (Eq. (1)) by employing a non-linear, least-squares approach.

$$
\mathrm{Me}_{2} \mathrm{SnCl}_{2}+\mathrm{H}_{2} \mathrm{~L}^{\mathrm{X}} \rightarrow\left[\mathrm{Me}_{2} \mathrm{SnCl}_{2} \cdot \mathrm{H}_{2} \mathrm{~L}^{\mathrm{X}}\right] \quad(\mathrm{X}=1-5)
$$

Also, the free energy change, $\Delta G^{\circ}$, of the complexes were determined by $\Delta G^{\circ}=-R T \ln K_{\mathrm{f}}$, at 25 ${ }^{\circ} \mathrm{C}$ (Table 4). As the results show, In the para substituted Schiff base ligands, the formation constants varies as can be expected according to the electronic effects of the substituents at position 5. Thus, the formation constants decreases according to the sequence $\mathrm{OMe}>\mathrm{H}>\mathrm{Br}>$ $\mathrm{Cl}>\mathrm{NO}_{2}$. This is somewhat in agreement with decreasing electron releasing character of the substituents in the same direction, which result in a decrease in basicity of the phenolic oxygen groups of the ligand, and consequently decreased tendency toward complex formation. The withdrawing functional groups make the Schiff base as a poor donor ligand and decrease the formation constants while the electron donor group increasing the formation constants because they leads to increase the donor ability of Schiff base ligands. Therefore, the ligands having $\mathrm{NO}_{2}$ group, $\left[\mathrm{H}_{2} \mathrm{~L}^{5}\right]$, have the smallest formation constants while the ligands with OMe group, $\left[\mathrm{H}_{2} \mathrm{~L}^{2}\right]$, have the highest because $\mathrm{OMe}$ is a donating group. Therefore, in the stabilization of the 
complexes, the donation power of the Schiff base is important, and hence their formation constants, $K_{\mathrm{f}}$, with donation are higher.

Table 4. The formation constants and the free energy values of tin(IV) complexes at $25^{\circ} \mathrm{C}$ in DMF.

\begin{tabular}{|c|c|c|}
\hline Complexes & $\log K_{\mathrm{f}}$ & $\Delta G^{\circ}\left(\mathrm{kJmol}^{-1}\right)$ \\
\hline$\left[\mathrm{Me}_{2} \mathrm{SnCl}_{2} \cdot \mathrm{H}_{2} \mathrm{~L}^{\mathrm{1}}\right]$ & $7.47(0.11)^{\mathrm{a}}$ & $-42.54(0.27)$ \\
\hline$\left[\mathrm{Me}_{2} \mathrm{SnCl}_{2} \cdot \mathrm{H}_{2} \mathrm{~L}^{2}\right]$ & $7.63(0.13)$ & $-43.51(0.32)$ \\
\hline$\left[\mathrm{Me}_{2} \mathrm{SnCl}_{2} \cdot \mathrm{H}_{2} \mathrm{~L}^{3}\right]$ & $7.21(0.09)$ & $-41.12(0.22)$ \\
\hline$\left[\mathrm{Me}_{2} \mathrm{SnCl}_{2} \cdot \mathrm{H}_{2} \mathrm{~L}^{4}\right]$ & $7.17(0.12)$ & $-40.89(0.29)$ \\
\hline$\left[\mathrm{Me}_{2} \mathrm{SnCl}_{2} \cdot \mathrm{H}_{2} \mathrm{~L}^{5}\right]$ & $6.93(0.06)$ & $-39.52(0.14)$ \\
\hline
\end{tabular}

${ }^{\mathrm{a}}$ The numbers in parentheses are the standard deviations.

\section{Antibacterial activity results}

The free Schiff base ligands and their corresponding tin(IV) complexes were tasted against the selected bacteria E.coli (G-) and S. aureus $\left(\mathrm{G}^{+}\right)$. The measured zones of inhibition against of various microorganisms are summarized in Table 5. All the tested compounds showed good biological activity against microorganism. It is found that the complexes have higher antimicrobial activity than the free ligands. This can be explained on the Tweedy's chelation theory [33]. The lipid membrane that surrounds the cell favors the passage of only lipid soluble materials due to which lipophilicity is an important factor which controls the antimicrobial activity. On chelation, the polarity of the metal ion will be reduced to a greater extent due to the overlap of the ligand orbital and partial sharing of the positive charge of the metal ion with the donor groups. Further, it increases the delocalization of p-electron over the whole chelate ring and hence enhances the liposolubility of the complexes. This increased liposolubility enhances the penetration of the complexes into the lipid membrance, the lipophilic group to derive the compound through the semipermeable of the cell, and blocks the metal binding sites in the enzymes of the microorganism.

Table 5. The Growth inhibition zone of the Schiff base ligands and their Sn(IV) complexes.

\begin{tabular}{|c|c|c|c|c|c|c|c|c|c|c|c|}
\hline \multirow[t]{2}{*}{ Bacteria } & \multirow{2}{*}{$\begin{array}{c}\text { Standard } \\
\text { (Strepto- } \\
\text { mycin) }\end{array}$} & \multicolumn{10}{|c|}{ Zone of inhibition in $\mathrm{nm}(25 \mu \mathrm{g} /$ disc $)$} \\
\hline & & $\mathrm{H}_{2} \mathrm{~L}^{1}$ & $\begin{array}{c}{\left[\mathrm{Me}_{2} \mathrm{SnCl}_{2} .\right.} \\
\left.\mathrm{H}_{2} \mathrm{~L}^{1}\right]\end{array}$ & $\mathrm{H}_{2} \mathrm{~L}^{2}$ & $\begin{array}{c}{\left[\mathrm{Me}_{2} \mathrm{SnCl}_{2} .\right.} \\
\left.\mathrm{H}_{2} \mathrm{~L}^{2}\right]\end{array}$ & $\mathrm{H}_{2} \mathrm{~L}^{3}$ & $\begin{array}{c}{\left[\mathrm{Me}_{2} \mathrm{SnCl}_{2} .\right.} \\
\left.\mathrm{H}_{2} \mathrm{~L}^{3}\right]\end{array}$ & $\mathrm{H}_{2} \mathrm{~L}^{4}$ & $\begin{array}{c}{\left[\mathrm{Me}_{2} \mathrm{SnCl}_{2} \text {. }\right.} \\
\left.\mathrm{H}_{2} \mathrm{~L}^{4}\right]\end{array}$ & $\mathrm{H}_{2} \mathrm{~L}^{5}$ & $\begin{array}{c}{\left[\mathrm{Me}_{2} \mathrm{SnCl}_{2} .\right.} \\
\left.\mathrm{H}_{2} \mathrm{~L}^{5}\right]\end{array}$ \\
\hline S. Aureus & 22 & 11 & 17 & 13 & 19 & 10 & 15 & 12 & 16 & 11 & 16 \\
\hline E. Coli & 24 & 10 & 15 & 12 & 16 & 8 & 18 & 10 & 19 & 12 & 15 \\
\hline
\end{tabular}

\section{Computational details}

The molecular properties of the complex structures under investigation were determined by density functional theory (DFT). The important structural analysis referring to bonding distances, bonding angles and dihedral angles parameters for all optimized structures of Sn(IV) complexes in the ground state configuration are gathered in Table 6. The fully optimized molecular structures of the tin(IV) complexes with atomic numbering are shown in Figure 2.

The structure shows that the complex is monomer in which the tin atom adopts a fivecoordinate geometry being ligated to two chloride ions, two carbon atoms of methyl group and $\mathrm{O}$ atom of the $\mathrm{H}_{2} \mathrm{~L}^{1-5}$ ligands. The Schiff base is coordinated to the tin atom as a neutral chelating agent in it is without deprotonated phenolic form via the hydroxyl oxygen atom. The two Sn-C142 and Sn-Cl43 bond lengths are similar and the calculated value is longer than SnC44, Sn-C45 and Sn-O38 (0.25-0.63 ̊). 


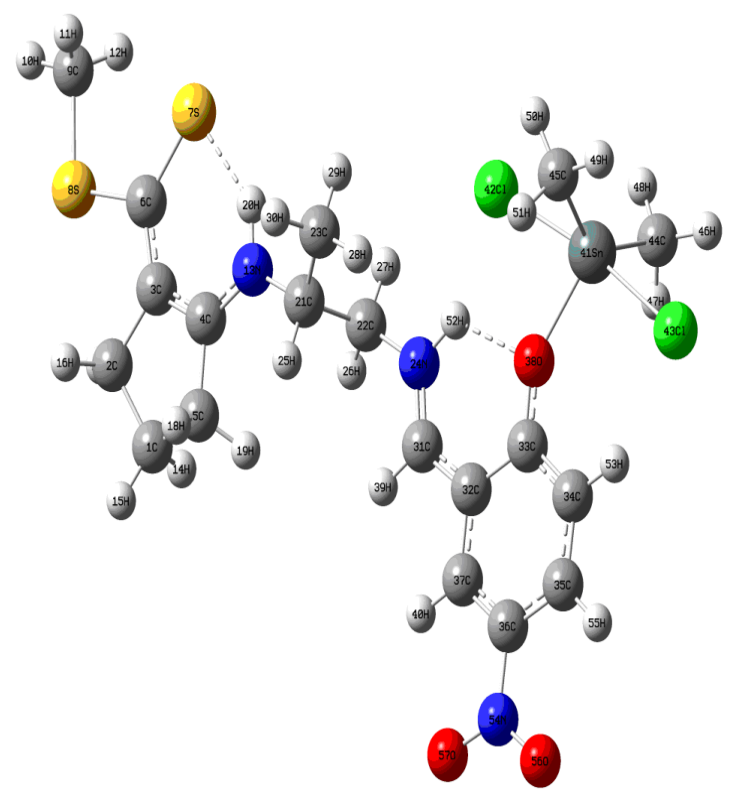

Figure 2. The optimized structures of the $\left[\mathrm{SnMe}_{2} \mathrm{Cl}_{2} \cdot \mathrm{H}_{2} \mathrm{~L}^{5}\right]$.

Table 6. Part of the data of bond distances $(\AA)$, bond angles and dihedral angles $\left({ }^{\circ}\right)$ obtained through B3LYP/LANL2DZ level of theory, labels for atoms can be found in Figure 2.

\begin{tabular}{|c|c|c|c|c|c|}
\hline Bond length $(\AA)$ & {$\left[\mathrm{Me}_{2} \mathrm{SnCl}_{2} \cdot \mathrm{H}_{2} \mathrm{~L}^{1}\right]$} & {$\left[\mathrm{Me}_{2} \mathrm{SnCl}_{2} \cdot \mathrm{H}_{2} \mathrm{~L}^{2}\right]$} & {$\left[\mathrm{Me}_{2} \mathrm{SnCl}_{2} \cdot \mathrm{H}_{2} \mathrm{~L}^{3}\right]$} & {$\left[\mathrm{Me}_{2} \mathrm{SnCl}_{2} \cdot \mathrm{H}_{2} \mathrm{~L}^{4}\right]$} & {$\left[\mathrm{Me}_{2} \mathrm{SnCl}_{2} \cdot \mathrm{H}_{2} \mathrm{~L}^{5}\right]$} \\
\hline Sn-C143 & 2.652 & 2.656 & 2.649 & 2.652 & 2.643 \\
\hline Sn-C142 & 2.673 & 2.669 & 2.668 & 2.664 & 2.665 \\
\hline Sn-O38 & 2.039 & 2.035 & 2.046 & 2.046 & 2.063 \\
\hline Sn-C44 & 2.120 & 2.120 & 2.119 & 2.119 & 2.118 \\
\hline Sn-C45 & 2.119 & 2.119 & 2.119 & 2.119 & 2.118 \\
\hline O38-H52 & 2.047 & 2.019 & 2.050 & 2.046 & 2.077 \\
\hline S7-H20 & 2.233 & 2.233 & 2.231 & 2.230 & 2.226 \\
\hline N24-C31 & 1.319 & 1.434 & 1.318 & 1.318 & 1.315 \\
\hline N13-C4 & 1.357 & 1.335 & 1.358 & 1.357 & 1.359 \\
\hline Bond angle ( $)$ & \multicolumn{5}{|l|}{} \\
\hline C142-Sn-C143 & 179.04 & 179.73 & 179.88 & 179.97 & 179.81 \\
\hline O38-Sn-C143 & 90.97 & 90.75 & 90.15 & 90.26 & 90.57 \\
\hline O38-Sn-C142 & 80.07 & 90.99 & 89.74 & 89.25 & 89.25 \\
\hline C143-Sn-C44 & 92.70 & 90.86 & 93.13 & 93.25 & 93.52 \\
\hline C142-Sn-C45 & 89.46 & 89.06 & 89.12 & 89.75 & 89.20 \\
\hline O38-Sn-C45 & 119.87 & 120.04 & 120.11 & 120.13 & 120.15 \\
\hline O38-Sn-C44 & 119.98 & 120.11 & 120.08 & 120.12 & 120.23 \\
\hline Dihedral angle ( $\left.{ }^{\circ}\right)$ & \multicolumn{5}{|l|}{} \\
\hline O38-C33-C32-C31 & -0.06 & -0.11 & -0.17 & 0.41 & -0.11 \\
\hline N13-C4-C3-C6 & 0.13 & -0.03 & 0.04 & 0.28 & 0.11 \\
\hline
\end{tabular}

The DFT estimated bond lengths are generally overestimated. The coordination geometry can be views as a trigonal bipyramidal with the two $\mathrm{C}$ atoms and $\mathrm{O}$ atom remains in the equatorial position and two $\mathrm{Cl}$ atoms in the axial position. In view of the bond angle, Cl42-Sn-Cl43 angles make approximately a $180^{\circ}$ angle and the calculated C45-Sn-C44, 
C45-Sn-O38 and C44-Sn-O38 angles are $120^{\circ}$ respectively (Table 6). On the basis of the results the tbp structure was confirmed.

The Sn(IV)-Schiff base ligand interaction is not lead to twisting of the ligand compared to the free ligand. In the optimized structure of the complexes cyclopentene and benzene ring are in the same plane. Their planes make approximately a $2^{\circ}$ dihedral angle to each other. The calculated O38-C33-C32-C31 and N13-C4-C3-C6 dihedral angles are near to each other. These molecules are not twisted, so that the 5-X substituents group $\left(5-\mathrm{OMe}, 5-\mathrm{H}, 5-\mathrm{Br}, 5-\mathrm{Cl}, 5-\mathrm{NO}_{2}\right)$ is in opposite orientation. The aromatic rings are essentially planar, where the bond lengths of $\mathrm{C}=\mathrm{C}(142.9-143.7 \AA)$ are in the expected range [34]. The two O38-H52 and S7-H20 asymmetrical intramolecular hydrogen bonds with distances 2.046-2.077 and 2.226-2.233 $\AA$ [35]. However, the two C-N bond lengths differ significantly of the two types of C-N bonds, the bond length for the imine nitrogen $(\mathrm{N} 24=\mathrm{C} 31)$ is $0.038-0.044 \AA$ shorter than that for primary amine nitrogen (N13-C4). These C-N bonds are essentially in the same plane with the plane of benzene and cyclopentene ring. The frontier orbital for all titled complex is plotted in Figure S2. The LUMO surface mostly delocalized within the non-metallic atoms, and for the HOMO level, the $\mathrm{Sn}$ atom is overlapped. HOMO which can be thought the outermost orbital containing electrons tends to give these electrons such as an electron donor. LUMO can be thought the innermost orbital containing free places to acceptor electron, owing to the interaction between HOMO and LUMO orbitals, transition of $\pi \rightarrow \pi^{*}$ type was observed with regard to the molecular orbital theory. As shown in Figure S2 the HOMO is localized over the azomethine group and cyclopentene ring, while the LUMO is localized over the benzene ring and N13-C4 bond. The energy difference between HOMO and LUMO orbitals so called as energy gap is an important stability for structures [36, 37].

The HOMO-LUMO energy gap of the Sn(IV) complexes are shown in Table 7 and revealed that the energy gap reflect to the chemical activity of the complexes. A large HOMO-LUMO gap increases stability and decreases chemical reactivity. The results show the following trend in HOMO-LUMO gap for the complexes:

$\left[\mathrm{Me}_{2} \mathrm{SnCl}_{2} \cdot \mathrm{H}_{2} \mathrm{~L}^{2}\right]>\left[\mathrm{Me}_{2} \mathrm{SnCl}_{2} \cdot \mathrm{H}_{2} \mathrm{~L}^{1}\right]>\left[\mathrm{Me}_{2} \mathrm{SnCl}_{2} \cdot \mathrm{H}_{2} \mathrm{~L}^{3}\right]>\left[\mathrm{Me}_{2} \mathrm{SnCl}_{2} \cdot \mathrm{H}_{2} \mathrm{~L}^{4}\right]>\left[\mathrm{Me}_{2} \mathrm{SnCl}_{2} \cdot \mathrm{H}_{2} \mathrm{~L}^{5}\right]$

The $\left[\mathrm{Me}_{2} \mathrm{SnCl}_{2} \cdot \mathrm{H}_{2} \mathrm{~L}^{2}\right]$ complex has a large gap between all complexes. A large HOMOLUMO gap indicate explain the experimental formation constant values. So, the DFT calculations support the experimental formation constant. Absolute hardness is half of the HOMO-LUMO gap. According to the maximum hardness principle, greater hardness $(\eta)$ causes more stability in the molecule [38]. On the basis of the data in Table $7\left[\mathrm{Me}_{2} \mathrm{SnCl}_{2} \cdot \mathrm{H}_{2} \mathrm{~L}^{2}\right]$ complex have a higher hardness and is stable than the other complexes.

In order to obtain reliable and stable structures, vibration frequencies were calculated for all optimized complexes. Selected experimental and calculated FTIR vibration frequencies $\left(\mathrm{cm}^{-1}\right)$ of the complexes were listed in Table 2 . The calculated $\mathrm{C}=\mathrm{C}$ stretching frequency is somewhat different from the experimental data, may be due to the fact that the theoretical data calculated in gas phase. In $\left[\mathrm{Me}_{2} \mathrm{SnCl}_{2} \cdot \mathrm{H}_{2} \mathrm{~L}^{2}\right]$ predict stretching modes at 1750,1560 and $1477 \mathrm{~cm}^{-1}$ correspond to $\mathrm{C}=\mathrm{C}$ bond. $\mathrm{C}=\mathrm{C}$ bond near the 5 -OMe group vibrates at a higher frequency compared to the vibration of $\mathrm{C}=\mathrm{C}$ bond on the ring in the farthest position to 5-OMe. The $\mathrm{C}=\mathrm{C}$ stretching mode in cyclopentene rings is $1477 \mathrm{~cm}^{-1}$ which occurs at a lower frequency relative to the $\mathrm{C}=\mathrm{C}$ bond in the ring involving substituent. On the other hand, in $\left[\mathrm{Me}_{2} \mathrm{SnCl}_{2} \cdot \mathrm{H}_{2} \mathrm{~L}^{5}\right]$ complexes $\mathrm{C}=\mathrm{C}$ bond near the $5-\mathrm{NO}_{2}$ group vibrates at a lower frequency $\left(1470 \mathrm{~cm}^{-1}\right)$ compared to the vibration of $\mathrm{C}=\mathrm{C}$ bond on the ring in the farthest position to $5-\mathrm{NO}_{2}\left(1490 \mathrm{~cm}^{-1}\right)$ and the $\mathrm{C}=\mathrm{C}$ stretching mode in cyclopentene rings is appeared at $1474 \mathrm{~cm}^{-1}$. For $\mathrm{C}-\mathrm{O}, \mathrm{C}=\mathrm{N}$ and $\mathrm{Sn}-\mathrm{O}$ stretching frequency showed the agreement between the experimental and scale calculated frequencies.

Base on the optimized structure of the title compound at B3LYP/LANL2DZ level of theory, the atomic charge distributions for all atoms were calculated and the results are listed in Table 8 . 
Seen from this data, atomic electronegativity plays important roles for atomic charge distributions of the non-hydrogen atoms. Namely, between the two connecting atoms, the atom having bigger electronegativity will carry negative charges, while the atom having smaller electronegativity will carry positive charges. For example, when a carbon atom is connected with a nitrogen atom, the carbon atomic charges are positive values and the nitrogen atomic charges are negative values, since the nitrogen atom has bigger electronegativity than the carbon atom. However, when a nitrogen atom is joined with an oxygen atom, the nitrogen atom has positive charges and the oxygen atom has negative charges, since the oxygen atom has bigger electronegativity than the nitrogen atom. So, for the $\left[\mathrm{Me}_{2} \mathrm{SnCl}_{2} \cdot \mathrm{H}_{2} \mathrm{~L}^{5}\right]$ complexes (Table 8), the carbon atoms in cyclopentene and phenyl rings all carry negative charges, since the hydrogen atom has smaller electronegativity than the carbon atom, but C4, C21, C31, C33 and C36 have positive atomic charges. These carbon atoms were joined to nitrogen (imine and nitro group) and oxygen (phenolic group) atoms that have bigger electronegativity than the carbon atom. The N13 and N24 have negatively atomic charges but N54 carry positive charge, because N54 was joined to two oxygen atoms that have electronegativity than the nitrogen atom. On the other hand, for the non-hydrogen atom in Table 8, although atoms of N13, N22, N54 and the carbon atoms in phenyl and cyclopentene rings have negative charge values, steric effect hinders them to coordinate with $\mathrm{Sn}(\mathrm{IV})$ ions further. The phenolic oxygen of the ligand has most negative atomic charges, respectively and there is none steric effect hindered, so the phenolic oxygen donates more electron density to the tin atom which has highest positive atomic charge, leading to rather strong Sn-O bonding. This idea is supported by the IR data.

Table 7. The calculated properties for Sn(IV) complexes at B3LYP/Lan2DZ level of theory.

\begin{tabular}{|l|c|c|c|c|c|c|}
\hline Complexes & HF energies & HOMO/eV & LUMO/eV & gap/eV & Hardness & Dipole/ Debye \\
\hline$\left[\mathrm{Me}_{2} \mathrm{SnCl}_{2} \cdot \mathrm{H}_{2} \mathrm{~L}^{1}\right]$ & -979.0946 & -0.2125 & -0.1168 & 0.09568 & 0.04784 & 9.85 \\
\hline$\left[\mathrm{Me}_{2} \mathrm{SnCl}_{2} \cdot \mathrm{H}_{2} \mathrm{~L}^{2}\right]$ & -1093.5994 & -0.2127 & -0.1164 & 0.09638 & 0.04892 & 9.76 \\
\hline$\left[\mathrm{Me}_{2} \mathrm{SnCl}_{2} \cdot \mathrm{H}_{2} \mathrm{~L}^{3}\right]$ & -993.4285 & -0.2151 & -0.1262 & 0.08884 & 0.04473 & 7.76 \\
\hline$\left[\mathrm{Me}_{2} \mathrm{SnCl}_{2} \cdot \mathrm{H}_{2} \mathrm{~L}^{4}\right]$ & -991.6471 & -0.2146 & -0.1251 & 0.08947 & 0.04442 & 8.05 \\
\hline$\left[\mathrm{Me}_{2} \mathrm{SnCl}_{2} \cdot \mathrm{H}_{2} \mathrm{~L}^{5}\right]$ & -1183.5643 & -0.2188 & -0.1372 & 0.08159 & 0.04079 & 5.98 \\
\hline
\end{tabular}

Table 8 . The computed Mulliken atomic charges ( $\mathrm{q} / \mathrm{e}$ ) of the $\mathrm{Sn}(\mathrm{IV})$ complexes.

\begin{tabular}{|c|c|c|c|c|c|c|c|c|c|}
\hline $\begin{array}{c}\text { Atom } \\
\text { No. }\end{array}$ & $\begin{array}{c}\text { Charge of } \\
{\left[\mathrm{Me}_{2} \mathrm{SnCl}_{2} .\right.} \\
\left.\mathrm{H}_{2} \mathrm{~L}^{1}\right]\end{array}$ & $\begin{array}{c}\text { Atom } \\
\text { No. }\end{array}$ & $\begin{array}{c}\text { Charge of } \\
{\left[\mathrm{Me}_{2} \mathrm{SnCl}_{2} .\right.} \\
\left.\mathrm{H}_{2} \mathrm{~L}^{2}\right]\end{array}$ & $\begin{array}{c}\text { Atom } \\
\text { No. }\end{array}$ & $\begin{array}{c}\text { Charge of } \\
{\left[\mathrm{Me}_{2} \mathrm{SnCl}_{2} .\right.} \\
\left.\mathrm{H}_{2} \mathrm{~L}^{3}\right]\end{array}$ & $\begin{array}{l}\text { Atom } \\
\text { No. }\end{array}$ & $\begin{array}{c}\text { Charge of } \\
{\left[\mathrm{Me}_{2} \mathrm{SnCl}_{2} .\right.} \\
\left.\mathrm{H}_{2} \mathrm{~L}^{4}\right]\end{array}$ & $\begin{array}{c}\text { Atom } \\
\text { No. }\end{array}$ & $\begin{array}{c}\text { Charge of } \\
{\left[\mathrm{Me}_{2} \mathrm{SnCl}_{2} .\right.} \\
\left.\mathrm{H}_{2} \mathrm{~L}^{5}\right]\end{array}$ \\
\hline C1 & -0.39089 & C1 & -0.39088 & C1 & -0.39085 & $\mathrm{C} 1$ & -0.39091 & $\mathrm{C} 1$ & -0.39064 \\
\hline $\mathrm{C} 2$ & -0.43132 & $\mathrm{C} 2$ & -0.43135 & $\mathrm{C} 2$ & -0.43139 & $\mathrm{C} 2$ & -0.43130 & $\mathrm{C} 2$ & -0.43152 \\
\hline C3 & -0.17114 & $\mathrm{C} 3$ & -0.17162 & C3 & -0.17043 & C3 & -0.17093 & C3 & -0.16879 \\
\hline $\mathrm{C} 4$ & 0.31989 & $\mathrm{C} 4$ & 0.32095 & C4 & 0.31970 & $\mathrm{C} 4$ & 0.32021 & $\mathrm{C} 4$ & 0.31859 \\
\hline C5 & -0.45651 & C5 & -0.45634 & C5 & -0.45628 & C5 & -0.45677 & C5 & -0.45656 \\
\hline C6 & -0.29576 & C6 & -0.29485 & C6 & -0.29539 & C6 & -0.29526 & C6 & -0.29584 \\
\hline S7 & -0.17835 & S7 & -0.17922 & S7 & -0.17737 & S7 & -0.17824 & S7 & -0.17574 \\
\hline S8 & 0.24048 & S8 & 0.23833 & S8 & 0.24118 & S8 & 0.24078 & S8 & 0.24481 \\
\hline C9 & -0.73283 & C9 & -0.73295 & C9 & -0.73274 & C9 & -0.73280 & C9 & -0.73262 \\
\hline $\mathrm{H} 10$ & 0.23828 & $\mathrm{H} 10$ & 0.23815 & $\mathrm{H} 10$ & 0.23867 & H10 & 0.23859 & $\mathrm{H} 10$ & 0.23922 \\
\hline H11 & 0.24430 & H11 & 0.24420 & H11 & 0.24441 & H11 & 0.24455 & H11 & 0.24459 \\
\hline H12 & 0.24455 & $\mathrm{H} 12$ & 0.24450 & $\mathrm{H} 12$ & 0.24462 & H12 & 0.24443 & $\mathrm{H} 12$ & 0.24473 \\
\hline N13 & -0.63432 & N13 & -0.63324 & N13 & -0.63470 & N13 & -0.63469 & N13 & -0.63649 \\
\hline H14 & 0.21479 & H14 & 0.21486 & H14 & 0.21498 & H14 & 0.21483 & H14 & 0.21533 \\
\hline H15 & 0.22193 & H15 & 0.22209 & H15 & 0.22262 & H15 & 0.22256 & H15 & 0.22365 \\
\hline H16 & 0.22317 & H16 & 0.22312 & H16 & 0.22366 & H16 & 0.22360 & H16 & 0.22424 \\
\hline H17 & 0.23268 & H17 & 0.23274 & H17 & 0.23313 & H17 & 0.23297 & H17 & 0.23353 \\
\hline
\end{tabular}

Bull. Chem. Soc. Ethiop. 2019, 33(1) 


\begin{tabular}{|c|c|c|c|c|c|c|c|c|c|}
\hline H18 & 0.23485 & H18 & 0.23497 & H18 & 0.23522 & H18 & 0.23528 & H18 & 0.23574 \\
\hline H19 & 0.21385 & H19 & 0.21361 & H19 & 0.21233 & H19 & 0.21333 & H19 & 0.21225 \\
\hline $\mathrm{H} 20$ & 0.42768 & $\mathrm{H} 20$ & 0.42835 & $\mathrm{H} 20$ & 0.42814 & $\mathrm{H} 20$ & 0.42785 & $\mathrm{H} 20$ & 0.42760 \\
\hline $\mathrm{C} 21$ & 0.00832 & $\mathrm{C} 21$ & 0.00840 & $\mathrm{C} 21$ & 0.00852 & $\mathrm{C} 21$ & 0.00906 & $\mathrm{C} 21$ & 0.00871 \\
\hline $\mathrm{C} 22$ & -0.21861 & $\mathrm{C} 22$ & -0.21927 & $\mathrm{C} 22$ & -0.21951 & $\mathrm{C} 22$ & -0.21907 & $\mathrm{C} 22$ & -0.22009 \\
\hline $\mathrm{C} 23$ & -0.65050 & $\mathrm{C} 23$ & -0.65023 & $\mathrm{C} 23$ & -0.65009 & $\mathrm{C} 23$ & -0.65003 & $\mathrm{C} 23$ & -0.65036 \\
\hline N24 & -0.52220 & $\mathrm{~N} 24$ & -0.51875 & $\mathrm{~N} 24$ & -0.51493 & $\mathrm{~N} 24$ & -0.51578 & $\mathrm{~N} 24$ & -0.50685 \\
\hline $\mathrm{H} 25$ & 0.20859 & $\mathrm{H} 25$ & 0.20876 & $\mathrm{H} 25$ & 0.20879 & $\mathrm{H} 25$ & 0.20957 & $\mathrm{H} 25$ & 0.20975 \\
\hline H26 & 0.21670 & $\mathrm{H} 26$ & 0.21735 & $\mathrm{H} 26$ & 0.21848 & $\mathrm{H} 26$ & 0.21838 & $\mathrm{H} 26$ & 0.22074 \\
\hline $\mathrm{H} 27$ & 0.25905 & $\mathrm{H} 27$ & 0.26068 & $\mathrm{H} 27$ & 0.26092 & $\mathrm{H} 27$ & 0.26040 & $\mathrm{H} 27$ & 0.26171 \\
\hline $\mathrm{H} 28$ & 0.23191 & $\mathrm{H} 28$ & 0.23208 & $\mathrm{H} 28$ & 0.23145 & $\mathrm{H} 28$ & 0.23088 & $\mathrm{H} 28$ & 0.22933 \\
\hline $\mathrm{H} 29$ & 0.23666 & $\mathrm{H} 29$ & 0.23697 & $\mathrm{H} 29$ & 0.23685 & $\mathrm{H} 29$ & 0.23693 & $\mathrm{H} 29$ & 0.23749 \\
\hline $\mathrm{H} 30$ & 0.23095 & $\mathrm{H} 30$ & 0.23077 & $\mathrm{H} 30$ & 0.23191 & $\mathrm{H} 30$ & 0.23165 & $\mathrm{H} 30$ & 0.23378 \\
\hline $\mathrm{C} 31$ & 0.19811 & C31 & 0.20050 & C31 & 0.19888 & C31 & 0.19963 & $\mathrm{C} 31$ & 0.20384 \\
\hline $\mathrm{C} 32$ & -0.17752 & $\mathrm{C} 32$ & -0.16343 & $\mathrm{C} 32$ & -0.16423 & $\mathrm{C} 32$ & -0.16523 & $\mathrm{C} 32$ & -0.17003 \\
\hline $\mathrm{C} 33$ & 0.43794 & $\mathrm{C} 33$ & 0.41541 & $\mathrm{C} 33$ & 0.43415 & $\mathrm{C} 33$ & 0.43556 & $\mathrm{C} 33$ & 0.45503 \\
\hline $\mathrm{C} 34$ & -0.25877 & $\mathrm{C} 34$ & -0.23836 & C34 & -0.24049 & C34 & -0.24224 & $\mathrm{C} 34$ & -0.24620 \\
\hline $\mathrm{C} 35$ & -0.15174 & $\mathrm{C} 35$ & -0.23286 & $\mathrm{C} 35$ & -0.17078 & $\mathrm{C} 35$ & -0.16705 & $\mathrm{C} 35$ & -0.14433 \\
\hline $\mathrm{C} 36$ & -0.23880 & $\mathrm{C} 36$ & 0.30636 & C36 & -0.02224 & $\mathrm{C} 36$ & -0.13559 & $\mathrm{C} 36$ & 0.05368 \\
\hline $\mathrm{C} 37$ & -0.16987 & $\mathrm{C} 37$ & -0.20360 & $\mathrm{C} 37$ & -0.18880 & C37 & -0.18476 & $\mathrm{C} 37$ & -0.14223 \\
\hline $\mathrm{O} 38$ & -0.89355 & $\mathrm{O} 38$ & -0.91182 & $\mathrm{O} 38$ & -0.89643 & $\mathrm{O} 38$ & -0.89614 & $\mathrm{O} 38$ & -0.87587 \\
\hline H39 & 0.20791 & H39 & 0.21037 & H39 & 0.21102 & H39 & 0.21112 & H39 & 0.21538 \\
\hline $\mathrm{H} 40$ & 0.21822 & $\mathrm{H} 40$ & 0.23111 & $\mathrm{H} 40$ & 0.23616 & $\mathrm{H} 40$ & 0.23423 & $\mathrm{H} 40$ & 0.25461 \\
\hline Sn41 & 2.11270 & Sn41 & 2.11881 & Sn41 & 2.11314 & Sn41 & 2.11245 & Sn41 & 2.10597 \\
\hline $\mathrm{Cl} 42$ & -0.67568 & $\mathrm{Cl} 142$ & -0.68109 & $\mathrm{Cl} 142$ & -0.67684 & $\mathrm{Cl} 42$ & -0.67636 & $\mathrm{Cl} 42$ & -0.67159 \\
\hline $\mathrm{Cl} 43$ & -0.63161 & $\mathrm{Cl} 43$ & -0.63758 & $\mathrm{Cl} 143$ & -0.63248 & $\mathrm{Cl} 143$ & -0.63335 & $\mathrm{Cl} 143$ & -0.62693 \\
\hline C44 & -1.21620 & C44 & -1.21678 & $\mathrm{C} 44$ & -1.21547 & C44 & -1.21531 & C44 & -1.21391 \\
\hline $\mathrm{C} 45$ & -1.21656 & $\mathrm{C} 45$ & -1.21704 & $\mathrm{C} 45$ & -1.21588 & $\mathrm{C} 45$ & -1.21630 & C45 & -1.21432 \\
\hline H46 & 0.25331 & $\mathrm{H} 46$ & 0.25304 & $\mathrm{H} 46$ & 0.25436 & $\mathrm{H} 46$ & 0.25422 & $\mathrm{H} 46$ & 0.25583 \\
\hline H47 & 0.25015 & $\mathrm{H} 47$ & 0.24824 & $\mathrm{H} 47$ & 0.24915 & $\mathrm{H} 47$ & 0.24925 & $\mathrm{H} 47$ & 0.25005 \\
\hline $\mathrm{H} 48$ & 0.25488 & $\mathrm{H} 48$ & 0.25476 & $\mathrm{H} 48$ & 0.25568 & $\mathrm{H} 48$ & 0.25578 & $\mathrm{H} 48$ & 0.25681 \\
\hline H49 & 0.25359 & $\mathrm{H} 49$ & 0.25328 & $\mathrm{H} 49$ & 0.25456 & $\mathrm{H} 49$ & 0.25468 & $\mathrm{H} 49$ & 0.25603 \\
\hline H50 & 0.25424 & $\mathrm{H} 50$ & 0.25409 & $\mathrm{H} 50$ & 0.25501 & $\mathrm{H} 50$ & 0.25415 & $\mathrm{H} 50$ & 0.25609 \\
\hline $\mathrm{H} 51$ & 0.24934 & $\mathrm{H} 51$ & 0.24767 & H51 & 0.24850 & H51 & 0.24869 & $\mathrm{H} 51$ & 0.24940 \\
\hline H52 & 0.46656 & $\mathrm{H} 52$ & 0.47034 & H52 & 0.46844 & H52 & 0.46861 & H52 & 0.46681 \\
\hline $\mathrm{H} 53$ & 0.25507 & $\mathrm{H} 53$ & 0.25804 & H53 & 0.26224 & H53 & 0.26195 & H53 & 0.26449 \\
\hline H54 & 0.23104 & $\mathrm{O} 54$ & -0.57159 & $\mathrm{Cl} 54$ & -0.04965 & Br54 & 0.06355 & N54 & 0.44261 \\
\hline \multirow[t]{5}{*}{ H55 } & 0.22103 & C55 & -0.26197 & H55 & 0.25010 & H55 & 0.24837 & $\mathrm{H} 55$ & 0.26566 \\
\hline & & $\mathrm{H} 56$ & 0.22222 & & & & & $\mathrm{O} 56$ & -0.36307 \\
\hline & & H57 & 0.19393 & & & & & O57 & -0.38411 \\
\hline & & $\mathrm{H} 58$ & 0.19356 & & & & & & \\
\hline & & H59 & 0.23222 & & & & & & \\
\hline
\end{tabular}

In this study, we have synthesized and characterized five new tin(IV) complexes. Physicochemical measurements confirm the 1:1 Sn(IV) to ligand stoichiometry of the complexes. Thermodynamic properties of the prepared complexes have been investigated. The formation constant of the Schiff bases with dimethyltin(IV)dichloride in DMF decreases according to the following trend $\left[\mathrm{H}_{2} \mathrm{~L}^{2}\right]>\left[\mathrm{H}_{2} \mathrm{~L}^{1}\right]>\left[\mathrm{H}_{2} \mathrm{~L}^{3}\right]>\left[\mathrm{H}_{2} \mathrm{~L}^{4}\right]>\left[\mathrm{H}_{2} \mathrm{~L}^{5}\right]$. Biological activity of the ligands and their complexes against different bacteria revealed that the complexes have higher antibacterial activity as compared to the free ligands. We have used density functional theory (DFT) to compute the electronic and molecular structures. The calculated structural parameters for complexes are in good agreement with the experimental data, confirming the obtained geometries for them. The FTIR spectra of the complexes were recorded and the important bands were identified and compared. They can use for analysis of complexes, help to explain the

Bull. Chem. Soc. Ethiop. 2019, 33(1) 
behavior of their vibrational modes. The HOMO-LUMO energy gap of the $\mathrm{Sn}(\mathrm{IV})$ complexes was calculated. The energy gap reflects to the chemical activity of the complexes. A large HOMO-LUMO gap increases stability and decreases chemical reactivity. The results show the following trend in HOMO-LUMO gap for the complexes: $\left[\mathrm{Me}_{2} \mathrm{SnCl}_{2} \cdot \mathrm{H}_{2} \mathrm{~L}^{2}\right]>\left[\mathrm{Me}_{2} \mathrm{SnCl}_{2} \cdot \mathrm{H}_{2} \mathrm{~L}^{1}\right]$ $>\left[\mathrm{Me}_{2} \mathrm{SnCl}_{2} \cdot \mathrm{H}_{2} \mathrm{~L}^{3}\right]>\left[\mathrm{Me}_{2} \mathrm{SnCl}_{2} \cdot \mathrm{H}_{2} \mathrm{~L}^{4}\right]>\left[\mathrm{Me}_{2} \mathrm{SnCl}_{2} \cdot \mathrm{H}_{2} \mathrm{~L}^{5}\right]$

\section{ACKNOWLEDGEMENTS}

We are grateful to Islamic Azad University, Darab branch Council for their financial support. The authors express their sincere thanks to Dr. Banafsheh Esmaielzade (Department of Anatomy, Bushehr University of Medical Sciences, Bushehr, Iran) for providing biological data preparation and to Ghazal Mashhadiagha (Department of Chemistry, Shiraz University, Shiraz, Iran) for providing the part of the computational method data.

\section{REFERENCES}

1. Lima, V.S.; Lemos, S.S.; Casagrande, G.A. Tributyltin(IV) complexes with amino acidderived Schiff bases: X-ray and solution structures. Polyhedron 2015, 89, 85-90.

2. Devi, J.; Devi, S. Synthesis, characterization and antimicrobial evaluation of Schiff base complexes derived from [2,2-(ethylenedioxy)bis(ethylamine)] and 5-chlorosalicylaldehyde. Der Pharma. Chem. 2017, 9, 89-92.

3. Blunden, S.J.; Cussack, P.A.; Hill, R. The Industrial Use of Tin Chemicals, Royal Society of Chemistry: London; 1985.

4. Wang, F.; Yin, H.; Cui, J.; Zhang, Y.; Geng, H.; Hong, M. Synthesis, structural characterization, in vitro cytotoxicities, DNA-binding and BSA interaction of diorganotin (IV) complexes derived from hydrazone Schiff base. J. Organomet. Chem. 2014, 759, 8391.

5. Ali, N.; Khan, A.; Amir, S.; Amir Khan, N.; Bilal, M.; Synthesis of Schiff bases derived from 2-hydroy-1-naphthaldehyde and their tin(II) complexes for antimicrobial and antioxidant activities. Bull. Chem. Soc. Ethiop. 2017, 31, 445-456.

6. Kadhirvansivasam, K.; Sivajganesan, S.; Periyathambi, T.; Nandhakumar, V.; Chidhambram, S.; Manimekalai, R. Synthesis and characterization of Schiff base $\mathrm{Co}^{\mathrm{II}}, \mathrm{Ni}^{\mathrm{II}}$ and $\mathrm{Cu}^{\mathrm{II}}$ complexes derived from 2-hydroxy-1-naphthaldehyde and 2-picolylamine. Mod. Chem. Appl. 2017, 5, 1-6.

7. Elsherbiny, A.S.; El-Ghamry, H.A. Synthesis, characterization, and catalytic activity of new $\mathrm{Cu}(\mathrm{II})$ complexes of Schiff base: Effective catalysts for decolorization of Acid Red 37 dye solution. Int. J. Chem. Kinet. 2015, 47, 162-173.

8. Yilmaz, F.; Karaali, N.; Şaşmaz, S.; Microwave-assisted synthesis of some nitrobenzimidazoles and their salicyl and isatin Schiff base. Bull. Chem. Soc. Ethiop. 2017, 31, 351-359.

9. Esmaielzadeh, Sh.; Shekoohi, Kh.; Sharif-Mohammadi, M.; Mashhadiagha, Gh.; Mohammadi, Kh. Synthesis, characterization, spectral Studies, antibacterial evaluation, thermodynamics and DFT calculations of dimethyltin(IV) dichloride Schiff base. Acta Chim. Slov. 2015, 62, 805-817.

10. Abu-Khadra, A.S.; Farag, R.S.; Abdel-Hady, A.E.M. Synthesis, characterization and antimicrobial activity of Schiff base (E)- $N$-(4-(2-hydroxybenzylideneamino)phenylsulfonyl) acetamide metal complexes. Am. J. Anal. Chem. 2016, 7, 233-245.

11. Kafi-Ahmadi, L.; Shirmohammadzadeh, L. Synthesis of $\mathrm{Co}(\mathrm{II})$ and $\mathrm{Cr}(\mathrm{III})$ salicylidenic Schiff base complexes derived from thiourea as precursors for nano-sized $\mathrm{Co}_{3} \mathrm{O}_{4}$ and $\mathrm{Cr}_{2} \mathrm{O}_{3}$ and their catalytic, antibacterial properties. J. Nanostruct. Chem. 2017, 7, 179-190. 
12. Mohammadikish, M. Four coordinate tin complexes: Synthsis, characterization, thermodynamic and theoretical calculations. Spectrochim. Acta, Part A: Mol. Biomol. Spectros. 2014, 117, 175-180.

13. Batral, N.; Malhotra, N.; Assija, S. Organotin(IV) complexes with ONS donor Schiff base ligand: synthesis, characterization and antimicrobial evaluation. J. Chem. Pharm. Res. 2014, 6, 194-200.

14. Nag, K.; Joardar, D. S. Metal complexes of sulphur-nitrogen chelating Agents. I. 2aminocyclo-pentene-1-dithiocarboxylic acid complexes of $\mathrm{Ni}(\mathrm{II}), \mathrm{Pd}(\mathrm{II})$ and $\mathrm{Pt}(\mathrm{II})$. Inorg. Chim. Acta 1975, 14, 133-141.

15. Bordas, B.; Sohar, P.; Matolcsy, G.; Berencsi, P. Synthesis and antifungal properties of dithiocarboxylic acid derivatives. II. Novel preparation of 2-alkylamino-1-cyclopentene-1dithiocarboxylic acids and some of their derivatives. J. Org. Chem. 1972, 37, 1727-1730.

16. Asadi, M.; Mohammadi, Kh.; Esmaielzadeh, Sh.; Etemadi, B.; Fun, H. K. Some new Schiff base ligands giving a NNOS coordination sphere and their nickel (II) complexes: Synthesis, characterization and complex formation. Polyhedron 2009, 28, 1409-1418.

17. Rahman, A.; Choudhary, M.; Thomsen. W. Bioassey Techniques for Drug Development, Harwood Academic: Amsterdam; 2001.

18. Frisch, M.J.; Trucks, G.W.; Schlegel, H.B.; Scuseria, G.E.; Robb, M.A.; Cheeseman, J.R.; Montgomery, J.A.; Vreven, J.T.; Kudin, K.N.; Burant, J.C.; Millam, J.M.; Iyengar, S.S.; Tomasi, J.; Barone, V.; Mennucci, B.; Cossi, M.; Scalmani, G.; Rega, N.; Petersson, G.A.; Nakatsuji, H.; Hada, M.; Ehara, M.; Toyota, K.; Fukuda, R.; Hasegawa, J.; Ishida, M.; Nakajima, T.; Honda, Y.; Kitao, O.; Nakai, H.; Klene, M.; Li, X.; Knox, J.E.; Hratchian, H. P.; Cross, J.B.; Adamo, C.; Jaramillo, J.; Gomperts, R.; Stratmann, R.E.; Yazyev, O.A., Austin, J.; Cammi, R.; Pomelli, C.; Ochterski, J.W.; Ayala, P.Y.; Morokuma, K.; Voth, G.A.; Salvador, P.; Dannenberg, J.J.; Zakrzewski, V.G.; Dapprich, S.; Daniels, A.D.; Strain, M.C.; Farkas, O.; Malick, D.K.; Rabuck, A.D.; Raghavachari, K.; Foresman, J.B.; Ortiz, J.V.; Cui, Q.; Baboul, A.G.; Clifford, S.; Cioslowski, J.; Stefanov, B.B.; Liu, G.; Liashenko, A.; Piskorz, P.; Komaromi, I.; Martin, R.L.; Fox, D.J.; Keith, T.; Al-Laham, M.A.; Peng, C.Y.; Nanayakkara, A.; Challacombe, M.; Gill, P.M.W.B.; Johnson Chen, W.; Wong, M.W.; Gonzalez, C.; Pople, J.A. Gaussian 03, Computer Program for Computational Chemistry, Gaussian Inc.: Pittsburgh PA, USA; 2003.

19. Becke, A.D. Density functional thermochemistry. III. The role of exact exchange. J. Chem. Phys. 1993, 98, 5648-5652.

20. Akbar Ali, M.; Abu Bakar, H.J.H.; Mirza, A.H.; Smith, S.J.; Gahan, L.R.; Bernhardt, P.V. Preparation, spectroscopic characterization and X-ray crystal and molecular structures of nickel(II), copper(II) and zinc(II) complexes of the Schiff base formed from isatin and $S$ methyldithiocarbazate (Hisa-sme). Polyhedron 2008, 27, 71-79.

21. Sedaghat, T.; Menati, S. Synthesis and spectroscopic characterization of new adducts of diorganotin(IV) dichlorides with an asymmetric schiff base ligand. Inorg. Chem. Commun. 2004, 7, 760-762.

22. Sihang, S.; Pareek, S.; Gupta, M.; Varshney, S.; Vareshney, A. Spectral and biological investigation of some new Sn(II) complexes with Schiff bases of amino acids. World $J$. Pharm. Pharm. Sci. 2014, 3, 2164-2176.

23. Kumar, S.B.; Bhttacharrya, S.; Dutta, S.K.; Tiekink, E.R.T.; Chaudhury, M. Mononuclear manganese(III) complexes of a heterodonor $\left(\mathrm{N}_{2} \mathrm{OS}\right)$ ligand containing thiolate-type sulfur: Synthesis, structure, redox and spectroscopic properties. J. Chem. Soc. Dalton Trans. 1995, 16, 2619-2626.

24. Sakthilatha, D.; Rajvel, R. The template synthesis, spectral and antibacterial investigation of new $\mathrm{N}_{2} \mathrm{O}_{2}$ donor Schiff base $\mathrm{Cu}(\mathrm{II}), \mathrm{Ni}(\mathrm{II}), \mathrm{Co}(\mathrm{II}), \mathrm{Mn}(\mathrm{II})$ and $\mathrm{VO}(\mathrm{IV})$ complexes derived from 2-Hydroxy acetophenone with 4-chloro-2,6-diaminopyrimidine. J. Chem. Pharm. Res. 2013, 5, 57-63. 
25. Yearwood, B. Reaction of tin(IV) chloride and tributyltin chloride with salben $\left({ }^{\mathrm{t}} \mathrm{Bu}\right)$ $\left[\right.$ salben $\left({ }^{\mathrm{t}} \mathrm{Bu}\right)=\mathrm{N}, \mathrm{N}^{\prime}-\left(\right.$ butylene)bis(3,5-di-tertbutyl)salicylideneimine] and salpen $\left({ }^{\mathrm{t}} \mathrm{Bu}\right)$ [salpen $\left({ }^{t} \mathrm{Bu}\right)=\mathrm{N}, \mathrm{N}^{\prime}$-(propylene)bis(3,5-di-tert-butyl)salicylideneimine] ligands. Int. $J$. Modern Chem. 2014, 6, 65-73.

26. Khan, R.; Tavman, A.; Gurbuz, D.; Arfan, M.; Cinarli, A.; Synthesis and structural characterization of $\mathrm{N}-(2-\{[(2 \mathrm{E})-2-(2-h y d r o y b e n z y l i d e n e) h y d r a z i n y l] c a r b o n y l\}-p h y n e l)-$ benzamide $\mathrm{HL}$ ) and its $\mathrm{Co}(\mathrm{II}), \mathrm{Fe}(\mathrm{III}), \mathrm{Cu}(\mathrm{II})$ and $\mathrm{Zn}(\mathrm{II})$ complexes. X-ray crystal structure of HL. Bull. Chem. Soc. Ethiop. 2018, 32, 111-124.

27. Sharma, R.K.; Singh, Y.; Rai, A.K. Synthesis and characterization of 5- and 6-coordinated monoorganotin(IV) complexes of 2-aminocyclopentene-1-carbodithioic acid and its N-/Salkyl derivative having NS and SS donor system. Phosphorus, Sulfur, Silicon, Rel. Elem. 2000, 166, 221-230.

28. Casas, J.S.; Sanchez, A.; Sordo, J.; Lopez, V.; Castellano, E.E.; Schpector, J.Z.; Argulles, M.C.R.; Russo, U. Diorganotin(IV) derivatives of salicylaldehydethiosemicarbazone. The crystal structure of dimethyl- and diphenyl-(salicylaldehydethiosemicarbazonato)tin(IV). Inorg. Chim. Acta 1994, 216, 169-175.

29. Otera, J. ${ }^{119} \mathrm{Sn}$ Chemical Shifts in five- and six-coordinate organotin chelates. J. Organomet. Chem. 1981, 221, 57-61.

30. Pellei, M.; Lobbia, G.G.; Mancini, M.; Spagna, R.; Santini, C. Synthesis and characterization of new organotin(IV) complexes with polyfunctional ligands. J. Organomet. Chem. 2006, 691, 1615-1621.

31. Kianfar, A.H.; Abroshan, I. Spectrophotometric study of complexation between some salen type Schiff bases and dimthyltin(IV) dichloride. Chem. Sci. Trans. 2013, 2, 17-24.

32. Leggett. D.L. Computational Methods for the Determination of Formatioin Constant, Plenum Press: New York; 1985.

33. Tweedy, B.G. Plant extracts with metal ions as potential antimicrobial agents. Phytopathology 1964, 55, 910-914.

34. Dal, H.; Suzen, Y.; Sahin, E. Synthesis, spectral studies of salicylidine-pyridines: crystal and molecular structure of 2-[(1E)-2-aza-2-(5-methyl(2-pyridyl)ethenyl)]-4-bromobenzen-1-ol. Spectrochim. Acta Part A: Mol. Biomol. Spectros. 2007, 67, 808-814.

35. Valente, E.J.; Eggleston, D.S. Structure of (phenyl)bis(4-hydroxybenzo-2H-pyran-2-one-3yl)methane. Acta Cryst. Sec. C 1989, 45, 785-789.

36. Lewis, D.F.V.; Ioannides, C.; Parke, D.V. Interaction of a series of nitriles with the alcohol inducible isoform of P450: computer analysis of structure activity relationships. Xenobiotica 1994, 24, 401-408.

37. Esmaielzadeh, Sh.; Mashhadiagha, Gh. Formation constants and thermodynamic parameters of bivalent $\mathrm{Co}, \mathrm{Ni}, \mathrm{Cu}$ and $\mathrm{Zn}$ complexes with Schiff Base ligand: Experimental and DFT calculations. Bull. Chem. Soc. Ethiop. 2018, 31, 159-170.

38. Zhou, Z.; Parr, R.G. New measures of aromaticity: absolute hardness and relative hardness. J. Am. Chem. Soc. 1989, 111, 7371-7379. 